\title{
EL ESTADO EN LA SOCIEDAD, EXPLICACIÓN DE CÓMO LA DISPOSICIÓN DE LAS BUROCRACIAS DETERMINA LOS ÓRDENES EN PAÍSES PERIFÉRICOS ${ }^{1}$
}

\author{
State within Society: Explanation of the Way Bureaucracy Disposition Determines Order in \\ Peripheral Countries
}

O Estado na sociedade, explicação de como a disposição das burocracias determina as ordens em países periféricos

RECIBIDO:8DEJULIODE 2015

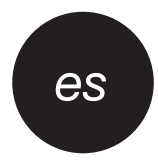

RESUMEN

Este artículo pretende a partir la teoría de Estado en sociedad de Joel Migdal entender cómo funcionan los Estados donde la separación entre lo público y privado no es real. Se aroumentará cómo en muchos países la imbricación entre lo privado y lo público obedece a la poca consolidación de los valores modernos en la sociedad, lo cual resulta en la conformación de instituciones o burocracias particulares diferentes del modelo legal racional propuesto por Weber. Finalmente, se procederá a describir, a manera de ejemplo, países en los que este fenómeno es más evidente.
EVALUADO:26DE AGOSTO DE 2015

Juan Pablo Henao Guzmán (Colombia)

Universidad de Antioquia Politólogo

pablosg-@hotmail.com

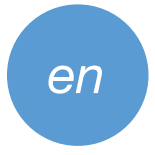

\section{ABSTRACT}

This article aims to understand the way the states where the division between public and private property is not real, based on Joel Migdal's Theory of State in Society. We analyze how in many countries, the interdependence between private and public property is due to the lack of consolidation of society's modern values, which results in the conformation of institutions or particular bureaucracies different from the rational legal model proposed by Weber. To conclude, we describe, as an example, some countries where this phenomenon is more evident.
PALABRAS CLAVE: Estado, modernidad, burocracia, Estado en sociedad.
KEYWORDS: State, modernity, bureaucracy, state in society.

\section{RESUMO}

Este artigo pretende a partir a teoria de Estado em sociedade de Joel Migdal entender como funcionam os Estados onde a separação entre o público e privado não é real. Se argumentará como em muitos países a imbricação entre o privado e o público obedece à pouca consolidação dos valores modernos na sociedade, o qual resulta na conformação de instituições ou burocracias particulares diferentes do modelo legal racional proposto por Weber. Finalmente, se procederá a descrever, a maneira de exemplo, países nos que este fenômeno é mais evidente.

PALAVRAS CHAVE: stado, modernidade, burocracia, Estado em sociedade.

PARA CITAR ESTE ARTÍCULO/TO CITE THIS ARTICLE/PARA CITAR ESTE ARTIGO:

Henao Guzmán,J. P. (2015). El Estado en la sociedad, explicación de cómo la disposición de las burocracias determina los órdenes en países periféricos. Panorama, 9(17) pp. 104-122.

1 El presente artículo es resultado de la investigación de Despojos de Estado: la consolidación de Gobiernos privados en zona de retirada estatal, proyecto CODI en la categoría de ciencias sociales y humanas, perteneciente al Grupo de Investigación Hegemonias, Guerras y Confictos del Instituto de Estudios Politicos de la Universidad de Antioquia y desarrollado entre 2012-2014. El investigador principal fue Wilmar Martinez Márquez. Para ampliar los resultados de esta investigación, véase Martínez, W. (2014). A modo de conclusión: despojos de Estado. La consolidación de Gobiernos privados en zonas de retirada estatal. En A la sombra del Leviatán: Estado, enemistad y protección en contextos de guerras asimétricas. Medellin: Universidad de Antioquia. Además, este articulo es derivado de la tesis laureada Reconfiguraciones contemporáneas del Estado, de Juan Pablo Henao Guzmán. 
un estado de guerra, violencia, desorganización y otro estado de paz y justicia (Martínez, 2014).

El Estado ha sido uno de los objetos de estudio más importantes en las ciencias sociales, ha sido cuestionado, deslegitimado, demonizado y santificado desde diversidad de enfoques e ideologías. Sin embargo, una visión ha triunfado históricamente sobre todas las diferentes apreciaciones y concepciones del Estado, la que supone la soberanía universal, la obediencia individual a la autoridad legítima expresada en la ley, aquella que promete la protección de las libertades y garantía de seguridad a cambio de obediencia y de renunciar al derecho de autodefensa. Se podría decir que esta teoría es la teoría bandera de la modernidad ${ }^{2}$. De la mano de autores, como Hobbes (1985) y Maritani (1983), se construyó una teoría normativa de carácter maximalista y universal. En esta se parte de un supuesto pesimista de individuo para luego normativizar el mejor modo de organización social de acuerdo con la naturaleza de dicho individuo. La teoría afirma que el poder concentrado y la soberanía absoluta es la respuesta a las penurias de una sociedad agresiva y desorganizada (Hobbes, 1985). Durante toda la modernidad el pensamiento ilustrado le dio matices a esta idea de soberanía, graduando la intensidad que debería tener el poder soberano sobre los súbditos, discutiendo si los derechos individuales dependían de la soberanía, o viceversa. Sin embargo, la idea central de que una sociedad debería organizarse en torno a la autoridad de un fuerte soberano nunca fue cuestionada (Uribe, 2001); un soberano que encarne la separación ente lo público y lo privado, que por medio de la instauración de un sistema legal permita la distinción entre

2 Entiéndase modernidad como lo desarrolló Habermas (2008) en su libro El discurso filosófico de la modernidad, en el que retoma los conceptos de modernidad y modernización. Para Max Weber aún era evidente la conexión interna, es decir, la conexión no contingente entre lo que llaman la modernidad y lo que llamó racionalismo occidental. Como racional describo aquel proceso de desencantamiento que condujo a Europa a que el desmoronamiento de las imágenes religiosas del mundo resultara en una cultura profana. Con las ciencias experimentales modernas, con las artes convertidas en autónomas y con las teorías de la moral y el derecho fundadas en principios, se desarrollaron esferas culturales de valor que posibilitaron procesos de aprendizaje de acuerdo en cada caso con la diferente legalidad interna de los problemas teóricos, estéticos y prácticos morales. Max Weber describe desde el punto de vista de la racionalización no solo la "profanación" de la cultura occidental, sino también la evolución de las sociedades modernas. Las nuevas estructuras sociales vienen dadas por la diferenciación de dos sistemas funcionalmente compenetrados entre si, que cristalizaron en torno a los núcleos organizativos, que son la empresa capitalista y el aparato estatal burocrático. Weber entiende este proceso como institucionalización de la acción económica y de la acción administrativa con arreglo a fines. A medida que la vida cotidiana se vio arrasada por el remolino de esta racionalización cultural y social, se disolvieron también formas tradicionales de vida diferenciadas en el mundo moderno, sobre todo, respecto de estamentos profesionales. Con todo esto, la modernización del mundo de la vida no viene determinada solo por estructuras de racionalidad con arreglo a fines. E. Durkeim y G. H Mead vieron el mundo de la vida determinarse por un trato, convertido en reflexivo. Con tradiciones que habian perdido su carácter cuasi natural, por la universalización de las normas de acción y una generalización de los valores, que en ámbitos de acción ampliados desligan la acción comunicativa de contextos estrechamente circunscritos y por pautas de socialización que tienden al desarrollo de identidades del yo. Esta es, a grandes rasgos, la imagen de la modernidad tal como se la representaron los clásicos de la teoría de la sociedad.
Estas ideas son las que durante siglos han determinado el análisis intelectual y científico sobre el Estado. La academia y la intelectualidad han partido del imaginario de un Estado fuerte hobesiano compuesto por un sistema legal y unas burocracias surgidas de un derecho positivo, en el cual la obediencia a ley es indiscutida y la participación política una realidad, y la esfera pública y privada están claramente delimitadas y separadas (Uribe, 2001).

Este sesgo intelectual, este presupuesto teórico asumido a veces como incuestionable, ha causado un gran daño a algunas vertientes de las ciencias sociales (Migdal,2011), puesto que se ha entendido la teoría como la realidad dando al objeto de estudio - los Estados realmente existentes- un estatus subordinado a la teoría, convirtiendo a la teoría del Estado moderno en la medida de todo tipo de organización política. Esto provocó que se entendiera cualquier diferencia con los presupuestos modernos como una desviación de lo correcto, una anormalidad o una patología. Es difícil para los teóricos del Estado imaginar sociedades donde los órdenes no pasen por el derecho, la democracia, la ley y la soberanía. Sin embargo, esta teoría ortodoxa y las derivadas de ella no pueden explicar realidades, como las africanas o las latinoamericanas, lugares donde los valores de la modernidad, tales como la libertad, la obediencia, la igualdad ante la ley y el ejercicio de la ciudadanía y la fe en la técnica no calaron completamente (Uribe, 2001).

La imposibilidad de aplicar estas teorías es evidente en gran parte de lo que en el siglo XX se llamó el Tercer Mundo, donde encontramos Estados que no son soberanos y que tienen que compartir y negociar el orden. Los carteles y las mafias en estas zonas ejercen un poder territorial y social que los Estados no pueden desconocer (Migdal, 2011). En estos contextos, existen grupos étnicos y familiares que controlan el Estado y conforman grupos de violencia privada a los cuales se les franquicia el uso de la fuerza y la economía estatal para así generar gobernabilidad (Hibou, 2013). También existen actores armados con pretensiones o sin ellas de soberanía, que ejercen un control territorial y social, pero que a pesar de ello han convivido y negociado el orden con unos Estados y unas formas legales de organización social relativamente fuertes (Uribe, 2001). En muchos aspectos y territorios particulares el Estado es un ente efectivo y en
Estado en

la sociedad,

explicación

de cómo la

disposición de

las burocracias

determina los

órdenes en

países periféricos 
Juan Pablo

Henao

Guzmán I

Panorama I

pp. 104-122|

Volumen 9 I

Número 17 |

Julio-diciembre |

2015 I

$106 \mid$ otros es ausente o se combina con otros poderes de facto de tipo societal. A pesar de que la distinción entre un estado de guerra y uno paz no es clara, de que las fronteras entre lo público y lo privado son difusas, de que la violencia es una práctica común y la Administración pública no está separada de los medios y recursos privados, el Estado en estos países está vigente, se reconoce y actúa en muchos lugares del territorio y desempeña un papel importante en la determinación del orden.

Para intentar entender y explicar estos convulsionados, diversos y contradictorios Estados, la academia ha usado referentes teóricos ideados para condiciones del Primer Mundo. Con las categorías tradicionales del Estado, se ha intentado entender a los países periféricos y como resultado se ha obtenido un juicio sobre el éxito político, económico y social de las sociedades y Estados periféricos o poscoloniales (Chabal y Daloz, 2001). Dichas comparaciones han sometido a dichos Estados a lecturas parcializadas, que, más que explicar su contexto político, lo condenan y desprecian como inferior, pueril, inacabado y, obviamente, subdesarrollado. Uribe (2001) sintetiza esta problemática para América Latina en este pequeño segmento:

\section{Hay que agregar que existe una cierta teleología bastante curiosa, que se dedica a describir lo que no son las democracias o lo que les falta para llegar a ser, de acuerdo con un orden supuestamente universal de modernidad política. Con base en este paradigma, las democracias realmente existentes en América Latina sólo serían desviaciones, imitaciones grotescas o francas equivocaciones culturales (p. 196).}

Este proceso analítico sesgado ha dejado a los países periféricos sin referentes válidos para la comprensión de su propia situación, puesto que las realidades descritas más arriba no caben en marcos interpretativos de teorías sociales afines a la modernidad. Otra vez Uribe (2001) concreta la problemática en una simple sentencia:

$$
\begin{aligned}
& \text { Pero, al mismo tiempo }{ }^{3} \text {, se ha convertido } \\
& \text { en obstáculo para la comprensión y la } \\
& \text { interpretación de la manera, siempre } \\
& \text { diferenciada y original, como arraigan y se } \\
& \text { difunden las instituciones y las prácticas } \\
& \text { asociadas con la democracia y el liberalismo } \\
& \text { en las distintas naciones que reconocen ese } \\
& \text { horizonte cultural (p. 196). }
\end{aligned}
$$

3 Refriéndose a la interpretación trágica y apocaliptica que se deriva de los análisis ortodoxos.
La teoría del Estado fallido ${ }^{4}$ es un ejemplo paradigmático del sesgo intelectual desde el cual parte gran número de los análisis para entender los Estados periféricos. Esta fue una teoría ideada para describir la situación que en la década de 1990 acontecía en los Balcanes y que luego extrapolo al caso Somalí (Román, 2009).

Dicha teoría no dio muchos réditos en varios de estos países, puesto que nunca explicó por qué en efecto en estos territorios ${ }^{5}$ la mayoría de la población reconocía el Estado vigente y obedecían a la ley de este; además que la población se reconocía como una nación unida y homogénea. La inaplicabilidad de teorías del Estado como estas radica en que incurren en el error de concebir la soberanía hobbesiana como la única forma en que el domino estatal puede manifestarse.

Sin embargo, desde hace algunas décadas, la academia viene reflexionando sóbre la necesidad de explorar otros enfoques teóricos que permitan la explicación de sociedades profundamente diversas con vestigios de Estados modernos o con Estados modernos relativamente consolidados. Autores como J. Comaroff y J. L. Comaroff (2009, 2013), Hibou (2013), Chabal y Daloz (2001) y Uribe (2001) evidencian estas realidades en especial en países que ellos denominan poscoloniales o periféricos, donde gran parte de la población ha pretendido tener una estructura estatal moderna en sociedades increíblemente diversas con costumbres y valores diferentes de los que se heredaron de la modernidad, cuyos valores sociales, patriarcales, tribales ${ }^{6}$ y religiosos son inseparables de la política y de lo que la modernidad podría llamar lo público (Chabal y Daloz, 2001).

Dado lo anterior, en este artículo se señalarán otras teorías válidas para explicar contextos que no se atienen estrictamente al ideal de Estado moderno. Teorías que permitan entender que la sociedad y el Estado pueden ocupar roles diferentes de los que la teoría política moderna les ha asignado. Ante esta reconfiguración de

\footnotetext{
4 La teoría de Estado fallido y sus similares, Estados fantasma (Reno, 2013), Estado sombra (Bilgin y Morton, 2002), y demás adaptaciones de la teoría ortodoxa del Estado, parten de la idea de un Estado fuerte y consolidado para analizar sociedades. Lo que logran es dar una explicación desde este paradigma a realidades ajenas a las europeas, estadounidenses o canadienses, en las que el Estado está más consolidado. Para Bilgin y Morton (2002), el término Estado fallido surgióa a principios de la década de 1990 asociado al colapso del Estado tras la caída del dictador Siad Barre, y la crisis de los Balcanes que devino en la debacle del Estado yugoslavo. Helman y Ratner (1993) definieron por vez primera qué era un Estado fallido: "El Estado que es incapaz de sostenerse como miembro de la sociedad internacional", lo cual implica luchas internas y una incapacidad de su sistema de justicia, militar y policiaco de mantener el control de su territorio.

5 Países como México, Colombia, El Salvador y Nicaragua.

6 Son muy numerosas las diferencias entre los órdenes modernos y los "tradicionales", la no separación de las funciones ejecutiva, judicial y legislativa, la no separación del campo espiritual y político, la organización alrededor de un patriarca con un estatus superior al de los demás individuo y el no reconocimiento de derechos por fuera de la comunidad son algunas de ellas (Bosch, 1998).
} 
posiciones y jerarquías, la categoría de burocracia se presenta como una alternativa viable para comprender las nuevas relaciones sociedad-Estado que surgen de esta reconfiguración y superposición de roles.

\section{ESTADO EN LA SOCIEDAD, TEORÍA DEL ESTADO DIFERENTE}

Se pueden encontrar casos donde la forma ortodoxa de Estado moderno no aplica o se dispone de una manera diferente de la concebida como correcta, y aun así dichos Estados están lejos de ser inviables. La academia en las últimas décadas ha encontrado casos donde el Estado y la sociedad se mimetizan para generar diversidad de órdenes políticos. Con el pasar del tiempo, los teóricos sociales han logrado reconocer estas formas de organización política que, en su mayoría, pretenden ser liberales y modernas (Estados) (Migdal, 2011; Uribe, 2001), pero que, en realidad, son órdenes que responden a una numerosa gama de influencias societales y económicas marcadas por numerosos flujos sociales ${ }^{7}$ y patrones de pensamiento ajenos a los heredados por la modernidad.

Los planteamientos de la modernidad han influido tanto en la teoría social y en el pensamiento académico que premisas como la separación sociedad civil y Estado se han tomado, en numerosas ocasiones, de manera acrítica e incuestionada (Alonso, 2014), invisibilizando, como es clásico del pensamiento moderno, las particularidades de la realidad social. Gracias a esto, las lecturas sobre la sociedad se han simplificado tanto que algunos teóricos liberales presentan como inviable toda sociedad que no base su organización en la idea de un individuo racional que mediante un contrato construya una sociedad civil separada y sometida al mismo Estado que esta inaugura (Migdal, 2011).

En contraposición a lo anterior, Migdal (2011) muestra que el Estado no es de ninguna manera un ente superior que se encuentra separado de la sociedad, como siempre las teorías modernas lo han mostrado. Por el contrario, el autor plantea la teoría del Estado en la sociedad, que consiste en mostrar cómo la estructura política, administrativa y jurídica del Estado se encuentra dentro de la sociedad, generando así una serie de relaciones en el

\footnotetext{
7 Entiéndase fujos sociales como todo aquello que escapa de la capacidad explicativa y creadora de la tradición del pensamiento de la modernidad occidental. Todo aquello que la teoría política, filosófica tradicional no abarca, tal como diferenciaciones étnicas, religiosas, familiares, incluso las maneras de distribución económica, que abandonan las formas del capitalismo clásico y el libre mercado. Uribe (2001) se refiere a este fenómeno denominándolo lo societal o el ethos sociocultural de una comunidad.
}

interior de ella, que escapan a las formas del derecho público y del derecho administrativo. En palabras del propio Migdal, "el Estado es una organización extendida dentro de la sociedad que coexiste con muchas otras organizaciones sociales formales e informales, desde familias y tribus hasta grandes empresas industriales" (2011, p. 75). Este enfoque muestra el Estado como un ente dinámico con relaciones de horizontalidad en muchos estamentos y sectores sociales. Con esto Migdal inaugurara una forma de interpretación en la que

\begin{abstract}
el Estado no es un aparato compacto y homogéneo, no es ese actor absolutamente coherente y sistémico que se postula en el enunciado "el Estado", y que su proceso de formación y relación con la sociedad depende de la manera en que se resuelven las relaciones conflictivas con las distintas redes de poder que median entre ambos (Bolívar, 2003, p. 8). Relaciones que operan por fuera de las clásicas antinomias y que presuponen un complejo campo de negociación, interacción y choque entre múltiples sistemas de reglas (Alonso, 2014, p. 13).
\end{abstract}

Según esto, la conformación del Estado está condicionada por diversidad de flujos sociales, religiosos y culturales, redes clientelares, economías formales e informales, violencias preexistentes y demás variables que la teoría ortodoxa no contempla (Comaroff y Comaroff, 2009). En concordancia con Migdal (2011), Uribe (2001) afirma que el Estado
se trata, también, de una infinita trama de negociaciones e intermediaciones, semipúblicas, semiprivadas ${ }^{8}$, que tiene lugar en los universos locales y regionales entre los distintos actores, de estos, en conjunto o por separado, con las comunidades o con sectores de ella y con autoridades locales de diverso orden (p. 213).

Para Migdal (2011), el Estado es esencialmente una campo de lucha, de disputa de poderes, un campo

\footnotetext{
8 A estas relaciones los académicos les han dado la categoría de corrupción, y demás apelativos peyorativos. Lo que los análisis ortodoxos no ven es que estas formas de sociabilidad politica y de generación de gobernabilidad son inevitables. La teoría de Estado en sociedad tiene especial pertinencia en sociedades que nunca lograron erigir el Estado como un ente autónomo y, además, en las cuales ni el pensamiento moderno ni los valores del que este derivan se lograron establecer completamente. En este sentido, las sociedades africanas son un ejemplo. Chabal y Daloz (2001) lo ilustran: "Nuestro argumento es que el Estado en Africa nunca se institucionalizó apropiadamente porque nunca se emancipó de forma significativa de la sociedad" (p. 30). Otra afirmación que lo corrobora es la siguiente "El desarrollo del Estado moderno depende sobre todo de su emancipación gradual de las estructuras politicas establecidas en la sociedad" (p. 31).
}

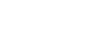


Juan Pablo

Henao

Guzmán I moderno. Se podría decir que el Estado pasa a ser un actor más dentro de un juego por poder y dominio, en el cual compite horizontalmente con otros actores sociales. El Estado visto como campo niega la más esencial característica del Estado moderno, la domesticación y exportación de conflicto, pues su característica es ahora el conflicto (violento o no) por la hegemonía sobre otros actores sociales, la dicotómica guerra y paz se queda entonces corta ante tal panorama diverso, múltiple y convulsionado (Alonso, 2014).

La teoría del Estado en sociedad plantea que el Estado está compuesto de dos elementos, lo que denomina la imagen y las prácticas (Migdal, 2011). La imagen estatal es lo que el Estado pretende ser, cómo se proyecta frente al individuo, la sociedad y otros Estados. La imagen del Estado es más o menos la misma alrededor del globo y esta obedece a los preceptos que la modernidad dicta sobre lo que debería ser el Estado; en términos generales, obedece a lo que se ha entendido como un Estado de derecho moderno. En palabras de Migdal,

\section{La imagen del Estado ha tendido a ser homologada de un Estado a otro, en especial la imagen del Estado moderno que tiene sus orígenes entre los siglos XV y XVII en el nordeste de Europa y que llegó a abarcar el mundo entero en la última mitad del siglo XX. A la inversa, las prácticas han tendido a ser diversas y aunque sin duda hay unos patrones comparativos reconocibles no es posible reconocerlos con precisión (2011, p. 34).}

Panorama I

pp. 104-122।

Volumen 9 I

Número 17 |

La imagen de un Estado fuerte, legítimo, justo y garantista de la seguridad (Martínez, 2014) da superioridad moral a este sobre otras formas de organización política. La ficción de que cada individuo es partícipe del poder de forma indirecta y es depositario de la soberanía permite a los Estados que pretenden ser modernos prácticas que de otra manera no serían toleradas. Además de lo anterior, el Estado debe lucir legal, burocrático y tecnificado, puesto que sin esta idea probablemente no podría ejercer el dominio al nivel que es necesario.
La imagen de los Estados está compuesta en gran parte por lo que la modernidad política plantea y complementada por lo que la ideología liberal y republicana dicta. Todo acto debe revestirse de legitimidad acudiendo a las formas modernas de cómo ejercer el poder, lo que Comaroff y Comaroff (2013) llaman la fetichización de la ley, concepto que se articula muy bien a la noción de imagen estatal ${ }^{9}$. La imagen del Estado debe mostrar que el Estado se encuentra organizado sobre la ley y el derecho, así como proyectar la ficción de que hay una soberanía única y todopoderosa sobre el territorio nacional y, por último, debe hacer creer a los ciudadanos que es posible la participación en igualdad de condiciones en la vida social y política de una comunidad.

Por su parte, las prácticas son lo que en efecto el Estado hace para ejercer gobernabilidad en la sociedad; es decir, son los métodos por los cuales el Estado ejerce y mantiene el domino sobre los individuos y la sociedad. Visas, pasaportes, delimitaciones físicas de las fronteras, tales como muros y vallas, policía fronteriza y local, un ejército nacional, son prácticas que van en la vía de concretar el Estado en la realidad para que no solo se queden como afirmaciones de tipo normativo y legal (Migdal, 2011). Migdal muestra cómo las prácticas pueden ir en detrimento y en franca contradicción con lo que históricamente se ha entendido que es un Estado moderno, lo que el mismo autor llama la imagen del Estado. "El desempeño cotidiano de los organismos y actores del Estado, sus prácticas, puede reforzar la imagen del Estado o debilitarla; puede consolidar o neutralizar la noción de fronteras territoriales y las que existen entre lo público y lo privado" (Migdal, 2011, p. 37).

No obstante, las complejas realidades donde se encuentra inmerso el Estado nos muestran cómo en muchas ocasiones para mantener el poder es necesario generar maneras alternas de dominación, maneras que disten de lo que se supone que debe ser el Estado. Puede existir la imposibilidad física del Estado de mantener unas "buenas prácticas" y que este tenga que adaptarse al contexto; contextos donde juegan actores sociales, incluso institucionales (López y Almazán, 2009), que impiden la actuación de un Estado central con vocación moderna, lo cual implica para el Estado negociar y ceder

9 El llamado fetichismo de la ley consiste en creer que la única y mejor forma de convivencia social está determinada por la normativa legal vigente. Se cree que esta es garantía para todos los miembros de la propia sociedad, por lo que y, en consecuencia, deben respetarse. Además que toda forma de poder y de dominio debe ejercerse al menos en apariencia de forma legal técnica para que esta sea válida y se considera legitima y deseable. 
en diferentes aspectos, tales como orden público o asignación presupuestal, para poder generar gobernabilidad y mantenerse vigente.

Como Migdal (2011) lo plantea, la idea de Estado moderno tiene trabajando a toda máquina a los Estados actuales y, en la mayoría de ocasiones, estos no son capaces de mantener los estándares que la misma teoría exige. Esto provoca un detrimento de la imagen, porque para una organización estatal con pretensiones de coherencia es imposible mantener prácticas acordes con la imagen de un Estado moderno, más aún si tiene que gestionar a una población con condiciones, ideas, creencias y valores alejados de lo que la modernidad dicta. Sin valores ciudadanos, tales como la creencia en la igualdad ante la ley, la secularización de la política y la fe en la técnica jurídica, es imposible que un Estado mantenga prácticas acordes con la imagen y al mismo tiempo genere gobernabilidad.

Uno de los requisitos (mas no el único) para que la $i m a-$ gen no se quede en simple retórica y las prácticas no la nieguen es que los valores de la modernidad deben estar bien arraigados en una comunidad. El respeto por la ley debe ser una realidad y el convencimiento de que el derecho positivo es la mejor y única forma de organización social debe ser imperativo; los valores de la libertad, la igualdad y la fe en la técnica deben pesar más en las cabezas de los ciudadanos que cualquier otro valor tribal, familiar o religioso (De León, 2008). Además, los ciudadanos han de tener la disposición a participar en la vida pública y tener la creencia de que es posible influir en el poder por medio de la política. Estos valores deben estar presentes en toda la sociedad para evitar que en el momento de actuar los individuos tomen en cuenta otros patrones de comportamiento y modifiquen la relación imagen-prácticas. Europa, los Estados Unidos, Canadá, Australia, son sociedades donde estos valores calaron y la diferencia entre las prácticas y la imagen estatal no es muy grande o, al menos, en la cotidianidad la interacción entre actores no provoca que se cuestione la existencia de un Estado consolidado, fuerte y legítimo. Asunto muy diferente en lo que se ha denominado las poscolonias ${ }^{10}$, Tercer Mudo o periferias, donde las realidades sociales, las condiciones históricas

10 Las poscolonias son aquellos territorios en los que las potencias occidentales coloniales (Inglaterra, España, Francia, Holanda, Portugal) establecieron colonias, es el caso de América Latina, África

y Asia septentrional. En estos lugares, las formas e ideas politicas occidentales, tales como la idea de Estado, mercado y ciudadanía, llegaron por medio de la colonización y se mezclaron con órdenes preexistentes (Mbembe, 2011). y su posición en la economía mundial hacen de la coherencia entre prácticas e imagen un propósito imposible de realizar (Migdal, 2011).

\section{BUROCRACIAS, VALORES E IMAGEN ESTATAL}

Weber es un autor que ha teorizado magníficamente el Estado Moderno, sus planteamientos han sido tomados como la medida y el estándar de todo Estado vigente (Migdal, 2011). En términos muy simples, para Weber, el Estado es "aquella comunidad humana que en el interior de un determinado territorio reclama para sí (con éxito) el monopolio de la coacción física legítima" (Weber, 1964,1980). Con esta definición, se puede afirmar que la teoría weberiana sintetiza las tesis modernas del Estado, pues la noción de monopolio de la fuerza es causa necesaria (mas no suficiente) para la instauración de la plena soberanía (Tilly, 2006). Lo anterior implica dos factores: primero, que para mantener la soberanía se requiere unos medios efectivos, como la fuerza; segundo, que el poder "soberano" necesita otras formas de dominio alternas al ejercicio directo de la fuerza para mantenerse vigente. Estas son los cuerpos administrativos, burocráticos e institucionales que evitan el uso constante de la fuerza y a su vez legitiman el dominio (Benjamin, 1973). Es en este punto donde el derecho, la ley y los sistemas burocráticos de organización comienzan a tomar el papel centran en la dominación de una sociedad; así el Estado se entromete en la cotidianidad de los individuos regulando por medio de la ley y las estructuras organizativas formales y burocráticas el accionar de los dominados, estableciendo marcos de lo correcto y lo incorrecto, lo que se sanciona y lo que se recompensa.

Weber conceptualizó el ideal de estos sistemas de dominación y los denominó burocracias legal-racionales, las cuales consisten en dar un carácter legal y formal a las normas de conducta, otorgar una impronta formal a las comunicaciones, dividir racionalmente el trabajo, imponer la impersonalidad en las relaciones, establecer jerarquías, instaurar la competencia técnica y meritocracia, separar los medios administrativos y los cargos burocráticos de la persona que los administra y profesionalizar los funcionarios. Todas las anteriores son las características clave de este modelo de organización (Weber, 1980).

I Panorama

I pp. 104-122

I Volumen 9

I Número 17

I Julio-diciembre

I 2015

| 109 
Juan Pablo

Henao

Guzmán I

Panorama I

pp. 104-122।

Volumen 9 I

Número 17 |

Julio-diciembre I

2015 I

11 Y retomando a Uribe (2001), no solo secular en términos religiosos sino también despojando la politica de lo familiar, lo económico, lo étnico y lo tribal.

12 Como en la Edad Media la sociedad organizó sus formas de gestión de recueros y administración de justicia acuerdo con lo que el dogma católico-cristiano instauraba. Un monarca con legitimidad divina, una Iglesia que controlaba la distribución y administración de justicia, la vigencia del derecho canónico, cuya legitimidad parte de la idea de santificación de los legisladores como porta-

Las burocracias legal-racionales se han tomado como la característica del Estado moderno. La consolidación de un orden legal racional es lo que distingue a este Estado moderno de otras formas de dominación, pues estas maneras tecnificadas y despersonalizadas de gestión de lo social son propias de un orden secular ${ }^{11}$ y moderno (Weber, 1980). El tipo de sistemas de administración de recursos y justica de una sociedad es evidencia de qué tanto caló la idea de Estado nación moderno en dicho territorio (Cruz, 1990). En efecto, la posibilidad de sostener un sistema burocrático parte de una legitimidad originada en un acuerdo social previo que, concediendo "un derecho, "pactado" u "otorgado", es estatuido de modo racional con arreglo a fines o valores" (Cruz, 1990). Esta legitimidad original permite a un poder establecido, como lo es el Estado moderno, organizar la sociedad de acuerdo con su matriz de valores, su discurso legitimador o su visión del mundo ${ }^{12}$. La burocratización es un indicio de modernidad en un Estado (Zabludovsky, 1986).

De hecho, como muestran Weber (1980) y Strayer (1981), la creación de cuerpos administrativos, separados formalmente de los estamentos sociales, es característico de la modernización de los Estados europeos. Este tipo ideal de organización se ha convertido en uno de los requisitos que todo Estado debe cumplir para ser reconocido como Estado. Todos los Estados intentan proyectar la apariencia de ser cuerpos administrativos coherentes y confiables, técnicamente viables y fieles a la normativa que sus respectivas constituciones inauguran (Migdal, 2011); en pocas palabras, burocráticos a la manera legal-racional. El orden legal-racional se ha convertido en parte esencial de lo que es la imagen de un Estado moderno. La dominación efectiva y la distribución de recursos debe hacerse mediante los medios legales, técnicos y modernos para que sea considerada correcta, deseable y justa; si, por el contrario, se toman otros estándares más "tradicionales”, se entiende como una mala gestión, incorrecta y corrupta. Si un criminal es asesinado en medio de la calle a causa de un crimen cometido, es considerado barbarie, pero si es sentenciado a muerte por medio de todos los procesos establecidos

dores de la justicia de Dios. es visto como la manera correcta de ejercer el castigo. Es por razones como esta, la legitimación que brinda el proceso, que todos los países intentan aparentar ser legales, técnicos, burocratizados, modernos, incluso si en realidad no lo logran.

El tipo de organización legal-racional es solo un tipo ideal de organización, pero los teóricos del Estado moderno lo han tomado como la medida de todo tipo de gestión de recursos y ejercicio de autoridad. En algunos países del mundo como los europeos, la realidad se acerca bastante a lo ideal. Pero, en gran parte del mundo, esto no es así; en las demás latitudes existen curiosas y sui generis adaptaciones de este tipo ideal a sus condiciones. Estas singulares modificaciones son vistas desde miradas occidentales como formas degradadas e insuficientes de organización social o, en el peor de los casos, son vistas como desorden y no se reconoce ningún tipo de orden subyacente. Se debe entender que no todo es blanco o negro, se tiende a olvidar que el modelo legal-racional burocrático es solo un tipo ideal. El mismo Weber mostró cómo en la realidad se dan formas alternas de burocracia, que obedecen a una forma sistematizada de poder y autoridad. El tipo ideal legal-racional se altera de acuerdo con las características propias de la sociedad que lo instaure ${ }^{13}$, estableciendo así regímenes particulares, mezclando características de la burocracia legal racional y las formas de dominación patrimonial. A este tipo de variaciones se les puede entender como burocracias patrimoniales (Prats, 2005); dentro de esta categoría, se pueden encontrar diversidad de órdenes no legal-racionales o, mejor aún, no modernos.

Existen tipos muy importantes de dominación patrimonial que en apariencia funcionan como burocracias, los que pertenecen formalmente a sus dirigentes se les llama carismático-hereditarios, monárquico-hereditarios o carismático-plebiscitarios; otros son materialmente racionales en muchas de sus partes, pero se encuentran construidos según una forma intermedia entre la burocracia y la influencia carismática de un gabinete o líder (Weber, 1984; Cruz, 1990). El tipo de la administración legal y racional es susceptible de aplicación universal y al intentarse aplicar se mezcla con diversidad de flujos sociales. Esta mezcla es inevitable,

\footnotetext{
13 Un orden puede ser burocrático con arreglo a resultados, la separación entre el funcionario y el cargo puede ser real, pero la forma de elegir al funcionario puede variar de la meritocracia al clientelismo. Son los casos de Colombia y México, donde el sistema de organización burocrático se altera de acuerdo con los valores de la comunidad, en los que es más importante el beneficio personal que el público.
} 
ya que las formas burocráticas entran a regir la vida cotidiana de los administrados provocando que estas dos se determinen mutuamente (Weber, 1984; Cruz, 1990) ${ }^{14}$.

En este orden de ideas, es viable decir que no porque un orden político ejerza el dominio por medio de formas alternas a la burocracia ideal es por sí mismo inestable o precario: en muchas ocasiones (como se mostrará más adelante) las formas burocráticas organizativas alternas son más complejas y estables que algunos órdenes burocráticos legal-racionales en sentido estricto. Estas son formas alternas de organización que, según los estudiosos de los contextos periféricos (Chabal y Daloz, 2001; Comaroff, 2006), predominan allí. Estos órdenes no solo conforman relaciones imagen-práctica no deseable desde una mirada occidental, sino que, además, no encajan en cuanto burocracias lo que debería ser un Estado moderno ${ }^{15}$.

\section{VALORES, INCOMPLETA EXPLICACIÓN}

Hay muchas razones por las cuales los órdenes de lo que se conoce como Tercer Mundo distan tanto de los órdenes del denominado Primer Mundo. Condiciones históricas, económicas y políticas han posibilitado el surgimiento de creencias particulares provocando que la forma de ejercer la política y gestionar los recursos en los países "desarrollados" diste en gran medida de los países periféricos. Por eso, en este artículo, se quiere señalar la importancia que tienen los valores de una sociedad y su relación con las burocracias para determinar un orden institucional determinado.

Si bien es cierto que desde Migdal todos los Estados son Estados en sociedad, entonces ¿por qué no todas las sociedades se comportan de igual manera? ¿Por qué no todos los países tienen un gran déficit en la relación entre imagen y prácticas? Una de las razones es porque

\footnotetext{
14 Hay que señalar que estas burocracias particulares no pueden hacer parte de un Estado moderno en sentido estricto, pues no cumplirían con los requerimientos básicos de profesionalización, meritocracia e independencia entre el funcionario y el dueño de los medios de administración.

15 Chabal y Daloz (2001) han ido por esta última linea buscando en estos otros órdenes lógicas válidas y explicando el porqué de estas variaciones. Una de las razones que el autor da es que el dominio en las colonias europeas que se dio entre el siglo XV y mitad del siglo XX se ejerció de una manera burocratizada, pero una burocracia no de formas modernas, sino que, gracias a los limitados recursos de que disponían los administradores coloniales, estos personalizaban las decisiones en individuos con poder, cuyos mandatos se emitían en clave tecnificada y formalizada; en otras palabras, eran de fondo personalistas y de forma burocráticos, característica propia de organizaciones políticas premodernas. Se podría decir que lo anterior apuntaba más a lo que Weber llama la patrimonializacion del Estado que a su burocratización (Zabludovsky, 1986). Esta es una explicación entre tantas de por qué estos órdenes difícilmente alcanzarán los estándares de países europeos yo norteamericanos.
}

existen valores y órdenes preexistentes que alteran la forma como las burocracias y las instituciones se relacionan con la sociedad y el individuo.

Según Douglas North, y la corriente del neoinstitucionalismo económico (las instituciones estatales y sus formas de funcionar determinan el entramado que el individuo debe sortear para cumplir sus objetivos. Incluso, si se parte desde el institucionalismo sociológico las instituciones también determinan los objetivos de los individuos, pues, en la medida en que los individuos persigan sus objetivos dentro de unos valores afines a las instituciones estatales, estas se consolidarán y perpetuarán ${ }^{16}$. También si se parte desde la sociología comprensiva, la relación entre valores e instituciones toma sentido, pues en este paradigma encontramos nociones que iluminarán la relación. Una es la noción de acción social o acción significativa (Scutz, 1993). Esta propuesta comprensiva se define como la acción que está dirigida a otro miembro del cuerpo social y solo encuentra sentido en su relación con él. La acción social tiene algunas adaptaciones de acuerdo con el contexto y la acción individual; sin embargo, para el tema que nos ocupa, solo se abordarán dos: la primera, la acción tradicional, la cual consiste en que el individuo actúa como siempre lo ha hecho en su contexto, este es un acto acrítico y mecánico, es una reacción a los estímulos normales que se encuentran en la sociedad. No hay en una acción así una elección consiente de medios para llegar a fines, sino que se rige por un patrón de costumbres y tradiciones (Schutz, 1993, p. 48). La segunda es la acción racional con arreglo a valores o acción afectual (Scut, 1993), la cual consiste en poner los medios y esfuerzos de la acción individual al servicio de la realización de un valor moral. En cierta medida es la elección consiente para la realización un valor.

Entonces, teniendo en cuenta todo lo anterior y entendiendo el Estado como Estado en sociedad (Migdal, 2011), se podría afirmar que los valores de una sociedad sí determinan inevitablemente la conformación de un tipo de orden social y político. La acción tradicional de los individuos condicionada por el contexto social determinaría y perpetuaría unas instituciones y burocracias

\footnotetext{
16 En el neoinstitucionalismo, las instituciones son entendidas de una manera mucha más amplia que en el institucionalismo tradicional. El primero abarca las instituciones como algo mucho mayor que el Estado, y el segundo las entiende solo como una disposición estatal y jurídica. Sin embargo, partir de la teoría de Estado en sociedad de Migdal permite entender el Estado en las mismas condiciones que cualquier otra institución social. Aun asi, para este caso particular, se le diferenciarán las instituciones estatales de las de las sociales.
}

I Panorama

| pp. 104-122

I Volumen 9

I Número 17 | Julio-diciembre 
Juan Pablo

Henao

Guzmán I

particulares, ya que los órdenes sociales y estatales no están separados. Ahora, la acción racional con arreglo a valores conduce a instaurar un tipo de orden de una manera intencional. Por ejemplo, si los valores modernos están plenamente consolidados en una sociedad, será más plausible que en dicha sociedad se encuentren instituciones modernas, legales, técnicas, burocráticas, incluso democráticas y liberales.

En relación con la propuesta planteada, el paradigma de la sociología comprensiva propuesto por Weber es muy pertinente para el análisis de los países periféricos y poscoloniales, ya que sitúa en otro lugar la noción de racionalidad, pues, al contrario de teorías de corte economicista y con influencia liberal, Weber concibe la idea de racionalidad de una manera relativa a cada individuo y a cada sociedad (Chabal y Daloz, 2001).

Nos basta simplemente con decir que el enfoque aportado por el propio Weber, el padre de la moderna teoría social, permitió desarrollar un análisis que estaba más en consonancia con las condiciones de África que la mayoría de los paradigmas actualmente en boga. De hecho, Weber definió la racionalidad según lo que los propios individuos y actores políticos creen que es racional y no según lo que los observadores externos podrían pensar sobre el particular (1980, p. 206).

Numerosos autores han apuntado o sugerido la relación entre la conformación de un Estado y los valores. Uno de ellos es Migdal (2011), quien muestra cómo los valores premodernos o no seculares intervienen en la práctica de un Estado. En Israel, por ejemplo, la religión ejerce una gran influencia sobre el sistema legal, los jueces fallan constantemente teniendo en cuenta los valores privados de poderosos grupos o líderes religiosos de gran influencia, como los rabinos, descartando así lo efectivamente estipulado en la ley racional, tecnificada

Panorama I pp. 104-122। Volumen 9 I Número 17 | cano, cómo los actores sociales se mueven entre la tradición tribal-societal y el pensamiento moderno, cómo en su sistema de creencias pueden hacer uso de la medicina moderna y de un médico brujo, cómo pueden reconocer 112 | a su prójimo como un igual (pues así lo demanda la ley positiva), cómo es un ser diferente y ajeno a su realidad debido a que pertenece a una etnia distinta o cómo los individuos pueden reconocerse parte de una nación y al mismo tiempo reconocer a un señor local miembro de su etnia como última autoridad. Bayard (1999) muestra el Estado africano como un Estado postizo, sin bases sociales o culturales homogéneas que permitan la instalación de una estructura administrativa coherente. E1 autor evidencia que la relación entre política y sociedad pasa por múltiples puntos de encuentro entre la forma societal de erguir el orden y la forma moderna dejada por la Colonia. Por su parte, Chabal y Daloz (2001) apuntan a lo mismo:

En África como en cualquier otra parte
del mundo, la política se desarrolla en un
mundo que incorpora ambas cosas (lo
tradicional y contemporáneo), en el que
estas tienen una importancia directa. Si bien
es cierto que las elites africanas se adscriben
de ordinario públicamente a la separación
entre lo irracional y lo profano, hay pruebas
abundantes de que su comportamiento
político es afectado por creencias religiosas
que poseen un peso cultural abrumador (p.
103).

Esta cita sustenta la hipótesis de que los valores de una sociedad tienen un papel en la conformación de la política y la forma de Estado, además, partiendo de una afirmación así se puede concluir que existen ejes de pervivencia histórica que determinan la política y el Estado en todas las sociedades, ejes que han construido sistemas de valores y creencias previos o diferentes de la modernidad y que son difíciles de remover. Esto último hace de la política no solo un asunto de decisiones, interés o de capacidad económica y técnica, sino que el papel de las creencias tiene un peso relativo en una sociedad y que en combinación con los demás determinantes históricos, sociales y económicos condicionan las formas en que se dispone la política y el Estado.

Se puede decir entonces que una de las causas por la que imágenes y prácticas distan tanto en algunas sociedades, en particular en la periferia del mundo, es que en dichas sociedades pueden estar vigentes valores diferentes de los modernos y, por ende, la estructura administrativa en estos territorios dista enormemente de la imagen de un Estado moderno, burocrático y tecnificado. Sus prácticas estarán encaminadas a satisfacer otro tipo de requerimientos diferentes de la eficiencia y demás características de un Estado moderno. Si los valores 
modernos, tales como la libertad, la igualdad, la meritocracia, la secularización y la fe en la técnica están consolidados en una sociedad, el hecho de que las estructuras organizativas del Estado no sean independientes de la organización social no sería mayor problema, puesto que los valores modernos y la legitimidad del Estado harán de la obediencia a la ley, el gobierno y el Estado en general un hecho. Y, por ende, el Estado necesariamente irá a un punto en que las prácticas e imágenes no disten significativamente. Las prácticas del Estado no distarán mucho de lo que el orden legal y constitucional normativicen. La eficiencia pública será posiblem, porque los funcionarios serán medidos con el estándar de la meritocracia y no otros criterios familiares, étnicos o políticos.

Es claro que esta no es la única razón por la que las imágenes y las prácticas pueden diferir. No es la intención de este artículo pretender que la combinación de valores e instituciones determinarían, exclusivamente, la distancia entre imágenes y prácticas. Difícilmente en las ciencias sociales actuales se podría dar cuenta de un fenómeno monocausal. Pueden en el mundo darse casos donde simplemente el Estado no tiene los recursos técnicos y prepuestales para mantener un aparato de justicia independiente de grupos sociales con poder, y tenga que recurrir a justicias locales que difieran de la forma moderna de ejercer justicia. $\mathrm{O}$ no pueda sostener un grupo profesional de militares para mantener sus fronteras o el orden público y, por ende, tenga que recurrir a mercenarios para custodiarlos. Todos estos casos y más se dan ${ }^{17}$, pero igualmente se dan casos donde es efectiva la existencia de estos aparatos de justica y militares, aunque la relación entre estos y la ciudadanía simplemente no es la esperada en un derecho público coherente con la norma constitucional ${ }^{18}$, sino que, como en el caso de Israel, la justicia se dé dentro de unos valores religiosos o de otro tipo.

\section{OTRAS FORMAS DE GESTIÓN ESTATAL DEL ORDEN Y EJERCICIO DE LA DOMINACIÓN DESDE EL ESTADO EN SOCIEDAD}

Los países de los territorios periféricos relacionan de maneras diferentes las prácticas y la imagen estatal de acuerdo con sus especificidades históricas. Sin embargo,

\footnotetext{
17 Estados en los que la económica estatal es inseparable del patrimonio personal del gobernante. El caso de los Somoza en Nicaragua es ilustrativo.

18 Más adelante se ejemplificará el caso de Brasil y México.
}

algo tienen en común, y es que la coherencia entre imagen y prácticas siempre deja mucho que desear. Los países de Asia, América y África son imposibles de homologar, pues tienen instituciones tan diversas como su propia historia, pero que todos apunten al mismo tipo moderno de conformación estatal como ideal ayuda a que se puedan detectar rasgos comunes. África y América Latina posen aspectos en común que sería pertinente señalar.

En estos territorios, la relación Estado-sociedad adquirió formas variadas $\mathrm{y}$ bastante distintas del modelo europeo, unas formas que, como dirían Comaroff y Comaroff (2009), son falsas o cuando menos sui generis. Los órdenes preexistentes y societales se combinaron con órdenes de tipo colonial y moderno (Chabal y Daloz, 2001), generando diversidad de Estados con gérmenes de modernidad. Comaroff y Comaroff (2009) muestran la diversidad de formas que toma la política y el Estado en América Latina, África y Asia, donde instituciones en apariencia modernas, racionales y técnicas conviven con la informalidad económica estrechamente asociada con la ilegalidad, también con grupos de violencia privada que ejercen dominio y gozan de la lealtad de la población. Estas son características comunes a estos territorios, los cuales han hecho de la violencia un requisito para las relaciones sociales y políticas.

Este contexto de aparente desorden, anarquía y caos convive con una imagen, una poderosa pretensión de estabilidad concretada en la creencia de que existe un Estado nación consolidado o, al menos, la intención de conservar esta ficción. La dupla sociedad-Estado es un elemento que podría dar luces para entender estas situaciones de "desorden".

\section{ÁFRICA Y EL ESTADO EN SOCIEDAD}

Existe una gran diversidad de órdenes políticos y sociales en África, generados por la imbricación entre lo societal y las instituciones estatales. E1 Estado moderno, en muchos países del África subsahariana, no es más que una ilusión, ya que la imagen del Estado es lo único que existe de Estado moderno en muchos países del continente. La fachada de un Estado mínimamente coherente se presenta ante la comunidad internacional, pero países como Uganda, Ruanda, Liberia solo podrían ser considerados asientos en la Organización de las Naciones Unidas (ONU), puesto que en el interior de dichos
Estado en

la sociedad,

explicación

de cómo la

disposición de

las burocracias

determina los

órdenes en

países periféricos 
Juan Pablo

Henao

Guzmán I

Panorama I

pp. 104-122।

Volumen 9 I

Número 17। países la unidad y coherencia del Estado moderno brilla por su ausencia. Sin embargo, estas sociedades tienen sus formas de gestionar el orden. Allí se ejerce el dominio en su manera más cruda: disponer de la vida y de la muerte de los dominados sin ningún tipo de control legal es una práctica de gobierno cotidiana (Mbembe, 2011). También la negociación de los recursos y de las exiguas cuotas de poder en el interior del Estado posibilita a las élites mantener la gobernabilidad y garantizar un mínimo de estabilidad. El papel de las burocracias (no legal-racionales) es determinante. Se ven ejemplos de privatización de lo público (Hibou, 2003), en los que las estructuras de cobro de impuesto se convierten en patrimonio de las élites de turno (Reno, 2013), adaptando así la forma ideal burocrática legal-racional a las costumbres y prácticas políticas locales. Este es el caso de la aduana en Camerún en la que se le deja dicha tarea a una empresa privada, la cual es propiedad de las familias de los sucesivos presidentes (Hibou, 2013), negando el principio que enuncia Weber de la separación de bienes administrativos del administrador. La situación de Camerún es bastante particular, pero todo apunta a que la causa es la misma de la cual se ha venido hablando, un Estado en sociedad con poca concordancia entre imagen y prácticas, entre valores e instituciones. El alto nivel de "corrupción" ${ }^{19}$ en Camerún sigue siendo una gran preocupación, a pesar de la presión internacional, de muchas leyes anticorrupción y planes para erradicarla concebidos en la última década, la práctica permanece inalterada en la vida diaria de los cameruneses. Samuel Ekoum presidente de la ONG camerunesa SOS Corruption, sostiene que más de $50 \%$ de los hogares cameruneses ha pagado al menos un soborno, además de que el Estado de Camerún pierde una media de 400000 millones de francos CFA (unos US\$832 millones) por año debido a la corrupción. Teniendo en cuenta que por concepto de su deuda externa paga en intereses alrededor de 3000 millones de dólares y su PIB en 2013 fue de US\$29000 millones, se hace necesario preguntar si realmente la corrupción no es norma en este país ${ }^{20} y$

19 Se tiende a ignorar que hay muchas maneras de relacionarse con el Estado y con la sociedad, unas consideradas incorrectas y otras correctas, pero no por ser consideradas incorrectas son menos válidas o eficientes. Es el caso de las dos siguientes: clientelismo, es una forma de confianza localizada - es decir, limitada - que crea un espiritu de facción y una jerarquía de legitimación de los comportamientos y de las fidelidades. Genera en los miembros de la clientela una acción oportunista excluyente frente a la cultura civica al instaurar dobles fidelidades y dobles moralidades, donde prevalecería la que corresponde a los intereses particulares de la clientela (De León, 2008); corrupción es el fenómeno social, politico y económico complejo que afecta a todos los paises. Ella socava instituciones democráticas, disminuye el ritmo del desarrollo económico y contribuye a la inestabilidad gubernamental ( Naciones Unidas, Oficina contra la Droga y el Delito, 2004).

20 http://datos.bancomundial.org/pais/camerun constituye una forma alternativa de gestión de bienes tanto públicos como privados.

El monopolio de la violencia y el ejercicio legítimo de la fuerza por parte de los Estados africanos también se da de formas ajenas a las acostumbradas por los Estados modernos. Mientras en Camerún los servicios de seguridad son prestados por una empresa privada de la cual el mismo ministro de Defensa es dueño ${ }^{21}$, en Argelia la violencia por parte del Estado y su mercenarios es usada como método para el desarrollo económico (Hibou, 2003). Ante la presencia del Grupo Islámico Argelino (GIA) y la necesidad de refinanciar su deuda externa, el Gobierno argelino se vio en la necesidad de patrocinar milicias civiles armadas (Martínez, 1998) para la conservación del orden público en los campos petroleros (Hibou, 2013), que, además, están en manos de compañías privadas. El caso argelino es replicado en su esencia en muchos países de África; la violencia y la seguridad entregada a franquicias y grupos privados es una clara negación de la separación entre lo público y lo privado, lo legal e ilegal. El Estado se desprende de su función primordial: la seguridad pública. Sin mencionar que el Estado y la guerra se han convertido en parte inherente del sistema de ascenso social en dicho país (Hibou, 2013).

La patrimonialización en Camerún y la descarga en Argelia del aparato de seguridad del Estado permiten decidir a los titulares del poder, de manera discrecional, sobre los puestos y cargos del aparato de seguridad del Estado. Además, la capacidad de usar la violencia en favor o en contra de intereses particulares se vuelve una manera de gestionar tanto el orden como la economía. La violencia del Estado se convierte en objeto con el cual transar (Misse, 2011), se ejerce en favor de intereses de élites locales o transnacionales. En Argelia, los cuerpos de seguridad del Estado están dispuestos en los campos petrolíferos propiedad de multinacionales, esto a cambio de sobornos y cuotas de poder (Hibou, 2013). Tanto en Argelia como en Camerún esta disposición de intereses beneficia a la élite en el poder, pues convertir el Estado y su fuerza en patrimonio personal y distribuirlo por medio de una extensa red clientelar es la forma como estas élites gestionan un orden conveniente para ellas y al mismo tiempo garantizan un mínimo de estabilidad. Ante este panorama, los habitantes de estos

21 Muy en vía de la patrimonialización. 
territorios no consideran la ley como un elemento de influencia en el momento de actuar. La relación con el espurreo sistema legal no es de obediencia o respeto o siquiera sentido de pertenencia. Para las élites, el Estado se convierte en un botín por capturar y para el resto de habitantes no es más que un acervo de violencia y fuerza que se ejerce de manera cruda y desnuda, afectando más que beneficiando a la gran mayoría de la población.

Argelia y Camerún privatizaron la forma de gestionar su económica política para la mantención del orden político. En estos escenarios, no se distingue lo privado de lo público, lo legal de lo ilegal, la gobernabilidad no conoce de las fronteras que la modernidad política creó. Por medio de la privatización de la economía o, dicho de una mejor manera, la patrimonialización de ella, los regímenes mantienen el control y el orden, pues el trabajo es un factor de control, y más en dichos países, donde la posibilidad del trabajo pasa por la decisión despótica de un gobierno sin sujeción a ningún tipo de control o ley (Mezzadra, 2012). El trabajo es tratado no como un derecho a garantizar sino como un privilegio con el cual negociar y controlar. Todo este sistema de gestión del orden se enmarca en un contexto global de neoliberalismo, en el que la "patrimonialización del Estado" se disfraza de achicamiento del Estado (inexistente) y eficiencia fiscal.

El antiguo Zaire o actual República Democrática del Congo es un evidente caso donde la imagen y las prácticas distan en gran medida. La personificación y patrimonialización de la política es el ejemplo perfecto de un Estado que solo existe en la imagen. El presidente Mobutu disponía de alrededor de US\$6 millones destinados a intervenir en política y economía a su voluntad, para así mantener el régimen viable y satisfacer a su extensa red clientelar por los medios que fueran necesarios (Reno, 2013). También él disponía de un aparato de justica que funcionaba como una forma de extender su control, personalizando las decisiones de la justicia para así gestionarse el favor y la lealtad de caudillos locales (Reno, 2013), comportamiento muy propio de una organización tribal donde la justicia se personaliza. El racismo y la xenofobia eran herramientas que se usaban en el ejercicio de la política, creando así un enemigo interno, incentivando las rivalidades tribales y étnicas e introduciendo de esta manera elementos societales a la política. El uso de las fuerzas militares y paramilitares era también discrecional y apuntaba hacia la distribución de poder, cargos y control de los "extranjeros" (Reno, 2013).

En países como Zaire la generación de orden y estabilidad tampoco conoce de límites o fronteras, de ilegalidad o legalidad, de privado o público, de económico o político. Tampoco diferencia lo estatal de lo social, las divisiones que la modernidad heredó no son más que informes oficiales ante la comunidad internacional. En la práctica real, se negocia con grupos privados de poder (insurgentes, grupos paramilitares, élites locales, familias, etc.), y se cede el control a estos o a multinacionales. Lo familiar se permea con lo público al igual que lo religioso y lo étnico, las estructuras administrativas del Estado no están separadas de ninguna manera de la sociedad. En estos contextos, siguiendo las palabras de Uribe (2001), lo societal se toma lo estatal.

\section{AMÉRICA LATINA, ¿A MEDIO CAMINO?}

Siempre se ha mostrado a América Latina como el punto medio entre África y los países desarrollados. Desde sus principios en el siglo XIX, el Estado latinoamericano fue construido y usufructuado por unas élites locales y centrales. Este, históricamente, ha hecho presencia en unas delimitadas regiones: la zona andina en Colombia o la zona portuaria en Buenos Aires (Argentina), son ejemplos de ello. En estas zonas protegidas, la población gozaba y aún goza de la máxima protección en derechos que estos Estados pueden proporcionar. Sin embargo, los territorios periféricos han padecido la existencia del Estado más de lo que se han beneficiado de él. Está protección diferenciada causó que muchos sectores de la población no otorgaran su lealtad al Estado central y conformaran sistemas propios de justica, gestión de recursos y organización social que respondieran a sus necesidades y condiciones (Uribe, 2001).

El Estado latinoamericano se expandió durante la segunda mitad del siglo XX, encontrándose así con estos órdenes que desafiaban su soberanía. Ante esta situación, diferentes fueron los caminos tomados por los Estados: la represión de estos órdenes, la negociación o en algunos territorios se siguieron manteniendo ignorados. Esto configuró una serie de Estados latinoamericanos muy diferentes entre sí y lejanos de los estándares de la teoría normativa. Los Estados latinoamericanos han sido fuertes, como lo ejemplifican los países del Cono Sur, pero no tan liberales y democráticos como
Estado en

la sociedad,

explicación

de cómo la

disposición de

las burocracias determina los

órdenes en

países periféricos 
Juan Pablo

Henao

Guzmán I

Panorama I

pp. 104-122 |

Volumen 9 I

Número 17|

\section{(Duncan, 2006).}

En las últimas décadas, la estructura de domino en las regiones tradicionalmente excluidas se ha conformado por medio del contubernio del Estado con los grupos de violencia privada que siempre se han desarrollado en las periferias. El poder militar y económico de los grupos privados, y el poder presupuestal y organizativo del Estado, han convivido, y en ocasiones aliado, para ejercer control sobre la población. Incluso gracias a su reciente poder económico y militar, estos grupos han logrado ganar influencias en regiones que tradicionalmente habían estado controladas por históricas élites locales en alianza con el Estado. Esto reconfiguró el escenario de lucha política en uno de negociación y pactos (Duncan, 2006). Ante la posibilidad de obtener grandes ganancias derivadas de los múltiples negocios ilegales e informales, la minería, el narcotráfico, la extorción, el secuestro, la captación de rentas ilegales, muchos de estos grupos y sectores del Estado han optado por la no confrontación armada directa o en numerosas ocasiones aliarse entre sí (Duncan, 2006), para así ejercer gobernabilidad y obtener rentas producto del control social y económico.

En Colombia, la figura del implementador de Migdal es particularmente ilustrativa para entender cómo estos grupos se han hecho con el control de las regiones. Para Migdal (2011), el implementador es aquel miembro del Estado encargado de hacer cumplir las directrices del poder central en las regiones. El cargo del implementador es una figura burocrática, está consagrada en la ley y dispone del imperio necesario para cumplir la función que la ley y el aparato administrativo disponen, en otras palabras, es un funcionario público. Sin embargo, que el cargo sea formalmente dependiente de la autoridad central no significa que el Estado tenga control sobre él; el implementador debe enfrentarse a una serie de realidades y condiciones locales que transforman su función, el cargo depende del Estado pero el individuo que ejerza este poder puede ser leal al señor fuerte local o alguno de estos grupos ilegales, poniendo en duda la capacidad del Estado de ejercer gobernabilidad sin la venia de los poderes ilegales periféricos. La figura del implementador, en estas circunstancias, causa que la imagen del Estado se mantenga fuerte y coherente, pero que sus prácticas disten en alguna medida de la imagen. En el caso colombiano, estos grupos privados han tenido tanta capacidad de influencia que la figura de un implementador cooptado se ha convertido en norma, incluso se ha convertido en la manera como el Estado negocia el orden en numeras zonas del territorio. 
Numerosos han sido los casos donde el implementador ha hecho parte de un orden ilegal de gestión de recursos y ejercicio del poder ajenos a las maneras estatales ortodoxas. En Medellín, grupos de violencia privada, cada vez más, se encargan de gestionar dinero y recursos provenientes de la misma Administración. El presupuesto participativo de dicha ciudad está siendo apropiado por estos grupos. El Estado entrega dinero a corporaciones para que estas ejecuten proyectos en favor de comunidades específicas. Sin embargo, muchas de estas corporaciones están infiltradas por miembros de estos grupos que gestionan y captan recursos estatales apropiándose de los contratos (Pareja, 2015), modificando así la vocación de los proyectos y los recursos que el mismo Estado destina.

México, por su parte, es una nación que obedece muy bien a lo que se ha descrito. Posee un Estado en apariencia moderno, pero en el fondo patrimonial con formas de gestión privadas y con una racionalidad no enfocada hacia la meritocracia o con miras hacia la eficiencia en la Administración pública. Como lo muestra Zabludovsky (1986), cuando habla del patrimonialismo en la segunda mitad del siglo XX en América Latina, aparte de algunas concesiones dadas por la influencia del constitucionalismo francés e inglés, las formas de hacer política y de ejercer dominación aún obedecen a la herencia colonial española de carácter patrimonial. En México, el poder político se ha concentrado en el ejecutivo, que, por medio de prebendas y favores políticos, da franquicias de poder. Estas son usufructuadas por los funcionarios públicos de todo tipo, desde la Procuraduría hasta la Policía Federal.Zabludovsky (1986), citando a Lorenzo Meyer, lo señala:

\section{Quienes hayan examinado el sistema político mexicano desde 1940 están de acuerdo en que el jefe del poder ejecutivo es donde convergen todos los canales de información $\mathrm{y}$ de donde parten todas las decisiones importantes; o sea el centro nervioso e indiscutible de la política mexicana, la forma que tomó la interacción entre el presidente, sus colaboradores y el resto de los actores políticos tuvo un carácter patrimonial ( $\mathrm{p}$. 37).}

Zabludovsky plantea que lo que se llama "corrupción" es simplemente la manera de gestión patrimonial de lo público y de distribución del poder que siempre ha estado en las sociedades latinoamericanas y particularmente en
México. La noción de corrupción aparece como categoría en el momento en que se impone la regla de gestión racional como estándar de medida; en otras palabras, se puede afirmar que esta forma de distribución del poder y ejercicio de dominación, donde el presidente abarca el poder de manera patriarcal, es la manera como el Estado mexicano se estructura, de una manera muy estable, por cierto. Aquí los derechos no se garantizan a menos que exista una contraprestación para él quien ostenta el poder. En consecuencia, existen grandes territorios, como el sur del país y sectores sociales tales como los indígenas, cuya relación con el Estado federal y regional es inexistente, o cuando menos precaria, gracias a su incapacidad de negociar con los funcionarios de turno.

Otro ejemplo de que los planteamientos modernos no son la única manera de constituir un Estado estable es Brasil, la potencia sudamericana. El país con la economía más sólida de América Latina ha apoyado su reciente desarrollo en la solidez de sus instituciones. Posee un Estado que en los últimos diez años ha tenido una gran expansión en derechos sociales y civiles. Nadie en el mundo se atrevería a cuestionar la viabilidad del Estado brasileño, incluso catalogarlo como Estado fallido. Muy lejos está Brasil de un colapso institucional y social total como, al parecer, pueden estar algunos países de África. Pero, aun así, no puede ser considerado un Estado moderno en un sentido estrictamente occidental. La relación de los ciudadanos con sus instituciones dista de un procedimiento formal y ortodoxo. Michael Misse (2013) lo muestra cuando describe qué es una "mercancía política"22. Misse muestra cómo la ley es ampliamente reconocida por la ciudadanía y la fuerza sobre la que esta se respalda es legítima y abrumadora. Sin embargo, el funcionamiento de las instituciones en la cotidianidad se sale de lo estipulado por el orden constitucional y legal. La relación de los ciudadanos con los entes administrativos, de seguridad y políticos obedece más a una serie de reglas sociales implícitamente pactadas (corrupción y clientelismo), en las que la moralidad, las condiciones económicas y sociales determinan las reglas de juego (Misse, 2013). La división entre lo

\footnotetext{
22 Denomino mercancias politicas al conjunto de diferentes bienes o servicios compuestos por recursos politicos (no necesariamente bienes o servicios públicos o de base estatal), que pueden ser constituidos como objeto privado de apropiación para intercambio (libre o forzada, legal o ilegal, criminal o no) por otras mercancias, utilidades o dinero. Lo que tradicionalmente se llama corrupción es uno de los tipos más principales de "mercancía politica". El "clientelismo" es, por su parte, una forma de poder basada en el intercambio de diferentes mercancias (politicas o económicas) en general legal o tolerada pero moralmente condenada por su carácter jerárquico y su estructura asimétrica. En Brasil, las fronteras entre clientelismo y corrupción por ser moralmente tenues tienden a reforzar y ampliar el mercado informal ilegal y criminal (Misse, 2009).
}

Estado en la sociedad, explicación de cómo la disposición de las burocracias determina los órdenes en países periféricos 
Juan Pablo

Henao

Guzmán I

Panorama I

pp. 104-122।

Volumen 9 I

Número 17।

Julio-diciembre |

2015 |

tencia son posibilitadas por agentes distintos del Estado. Lo que no se ve es que el Estado sí está presente en la negociación del orden con los grupos de violencia privados que controlan los mercados ilegales. Los grupos privados compran la mercancía que los funcionarios de todos los niveles estatales venden.

\section{LA PERIFERIA EN EUROPA}

Rusia es un buen ejemplo de la teoría de Estado en sociedad. En este país existen pétreas oligarquías, fuertes grupos sociales, sin los cuales el Estado ruso sería inviable. Estas poseen estrechas relaciones tanto con la burocracia estatal como con el crimen organizado. En el Estado ruso, el clientelismo y la corrupción son factores que constituyen el orden político, por lo que el peso de estos en la política es mayor que en cualquier país de Europa (Reno, 2013). El orden público depende, en gran medida, de las poderosas mafias rusas; los asesinatos, los secuestros, la venta de droga, son moneda corriente y las fuerzas del orden público no pueden y no quieren hacer nada al respecto. En gran parte del extenso territorio ruso, el Estado está ausente en derechos y en presencia administrativa, además, la participación democrática al estilo occidental no existe. Ante este nefasto diagnóstico, si partimos de la teoría clásica del Estado, no podríamos sino reconocer a Rusia como un Estado fallido o en vías de estarlo, pero en este momento dichas declaraciones no tienen asidero. Rusia tiene la historia de haber sido el Estado con más capacidad de control y de represión social de la historia del planeta. Nunca la fuerza de este Estado fue cuestionada ${ }^{23}$. Quince repúblicas estuvieron bajo su férreo control; en ellas toda disidencia era controlada y reprimida; los cuerpos de inteligencia más grandes y eficientes estuvieron al este de la Cortina de Hiero. Además, por mucho tiempo, los derechos sociales estuvieron garantizados mejor que en cualquier país de Occidente. En el presente, Rusia es una de las economías más sólidas y prósperas del mundo, su área de influencia en Asia central y el este de Europa está consolidada, posee el tercer ejército más grande del mundo, y con mayor capacidad de intervención después de los Estados Unidos; Rusia muestra con argumentos de sobra que la vía moderna de Estado nación no es la única viable.

Desde antes de la caída de la Unión Soviética, el orden ya se negociaba en la altas esferas de la Nomenclatura, donde los funcionarios del Partido Comunista y las mafias tenían estrechas relaciones (Gray, 1998). El orden ha sido y es negociado, la corrupción y el

23 Recordar que los servicios de inteligencia más grandes estaban al oeste de la cortina de bierro. 
clientelismo han sido el pegamento que ha mantenido a este país; y es que "en la Unión Soviética la corrupción no representaba un problema; era la solución para un sistema que de otra manera habría resultado inoperante" (Gray, 1998). Incluso, luego de la caída la Unión Soviética esta alianza oligarquía-Estado-criminalidad solo se exacerbó. En el momento en que los recursos y el dinero pararon de fluir, gracias al estancamiento de la economía, la única manera de sostener el Estado ruso y que la pluralidad interna de este no desgarra la nación fue privatizando, vendiendo toda la economía pública que se había logrado consolidar. Apropiaciones no registradas, ventas de múltiples empresas estatales muy por debajo de su precio real, la fragmentación y venta de todo el complejo militar industrial a particulares. Todo esto garantizó que el Estado ruso se conservara y hasta de hoy prosperara mucho más rápido que muchos de los antiguos países socialistas.

En Rusia, el Estado no es más que un elemento del régimen para mantener el orden, para armonizar las múltiples diferencias y tendencias que existen en una nación tan extensa y diversa. Sin embargo, el pueblo raso está comprometido con la ley y con el poder que de esta emana. El sistema judicial está lejos de colapsar, es eficiente e implacable. Rusia dista mucho de lo que podrían ser los países africanos, ya que posee un sistema de justicia fuerte y un sistema administrativo estable. Sin embargo, la relación entre la sociedad y el Estado es diferente de la moderna y diferente de la de un Estado colapsado.

Por otra parte, Italia es también muestra de cómo las sociedad y la forma de Estado moderno pueden conformar órdenes bastante estables sin tener el monopolio de la fuerza. Italia fue la cuna del Renacimiento y la Ilustración (Burke, 1936). Sin embargo, la conformación del Estado moderno fue tardía y diferente de los modelos típicos de Inglaterra y Francia. Italia siempre estuvo compuesta por una liga de ciudades Estado muchas veces aliadas y muchas veces beligerantes entre sí. Estas ciudades Estado lograron construir una unidad política frágil siempre amenazada por imperios, como el otomano, el francés o el austriaco o, en ocasiones, por las ambiciones de poderosas élites de alguno de los siete Estados federados.

Aunque este país estuviera permeado y fuera centro de la intelectualidad ilustrada, la conformación del Estado italiano y su nación tomó otra vía diferente de la aceptada. Estas diferencias causaron que el desarrollo del Estado y la economía en Italia tomaran vías distintas, creando así dos Italias (García, 1994). El norte rico, con un Estado consolidado y una economía industrial sólida (actualmente conocido como la Lombardía), y el sur del país compuesto por regiones, como Nápoles y Sicilia, donde el Estado tiene grandes falencias y la pobreza hace una importante presencia. A estas condiciones han respondido las famosas mafias italianas, que, ganando poder económico y social, han conseguido aliarse con grandes partes del Estado y su funcionarios; además de ejercer control sobre territorio rural y urbano (Pace, 2010). En Italia, las fronteras entre la economía informal, ilegal y legal son difusas, cuando no inexistentes; sin embargo, al igual que en Rusia, esta sociedad dista mucho de ser una sociedad fracasada, pues goza de una estabilidad tan grande y una influencia tan importante que la ha llevado a ser parte de G8.

Desde el final de la Segunda Guerra Mundial, la mafia ha sido protagonista en la conformación del Estado italiano. Existe una alianza entre los servicios secretos del Estado, la derecha y la mafia italiana para garantizar un tipo de orden que no va en la vía de un Estado de derecho y una democracia liberal (Pace, 2010): "Se trata de la demolición desde dentro del Estado de Derecho y de la democracia en beneficio de un nuevo tipo de régimen político" (p. 41). La mafia y parte de la estructura administrativa y de seguridad estatal han sido los constructores del tipo de Estado que ahora está vigente en Italia. Un orden que en apariencia es más liberal y moderno que muchos, pero que en su germen está compuesto de una manera similar a muchos países latinoamericanos y africanos. En Italia, los "grupos de poder privado"24 gestionan la lealtad de los habitantes del territorio, captan rentas producto del trabajo de la sociedad, incluso producen rentas producto de la economía tanto legal como ilegal. El Estado italiano es otro caso de un Estado en sociedad evidente. Como lo muestra Tilly (2006), la evolución del Estado necesita grupos sociales que lo impulsen y, en el caso italiano, este papel ha sido cumplido, al menos desde la Segunda Guerra Mundial, por las mafias. En palabras de Pace, "la República italiana

\footnotetext{
24 Para Mbembe (2011, p. 79), esto constituye una forma inédita de estructuración social que tiene actualmente en los Estados africanos el ejemplo más claro. Es el resultado de una brutal revisión de las relaciones entre el individuo y la comunidad, entre los regimenes de la violencia, los de la propiedad y el orden tributario. En Italia, las mafias son un eje que articula al individuo y la comunidad. Además, como es bien sabido, usan la violencia como forma de gobierno y control territorial y gestión de la propiedad en la comunidad donde intervienen.
} 
Juan Pablo

Henao

Guzmán |

\section{CONCLUSIONES}

En definitiva, el Estado en Sociedad se perfila como un paradigma que explica numerosos órdenes políticos contemporáneos, que no encajan en el estricto ideal de las teorías Modernas del Estado. Migdal (2011) permite entender la multiplicidad de conflictos que se encuentran en todo Estado contemporáneo y, en particular, los Estados de la periferia, puesto que en estas últimas latitudes la unión entre sociedades y Estados es más patente. Se concluye, pues, que en las sociedades periféricas no existen Estados colapsados, solo Estados diferentes de la norma históricamente aceptada. No se puede decir que los países periféricos carezcan de Estado o de algún tipo de orden político, aunque sí podría hablarse de un déficit entre la imagen y las prácticas estatales, lo cual hace que se perciba estas formas de Estados como insuficientes o indeseables.

Migdal muestra cómo históricamente la academia ha cometido un error al analizar el Estado; este error consiste en reificarlo. El Estado no es de ninguna manera un ente autónomo o concreto, pues no existe una esencia del Estado que lo determine ontológicamente. Lo que realmente existe son prácticas estatales condicionadas por sus circunstancias históricas, por la disposición actual del país en la división del trabajo internacional, por las decisiones que todos los días los habitantes toman para vivir, por las diferentes culturas dentro de la misma nación, por aquellos grupos que no encajan en la construcción ideal de ciudadano que cada nación construye, por grupos de poder transnacionales o locales. Todo esto enmascarado por la imagen, una teoría normativa, un discurso que justifica la existencia de este mismo orden, orden que puede ser totalmente contario a lo que la imagen del Estado moderno dicta. En pocas palabras, el Estado no es un ente, es un campo de constantes luchas, vetos y conflictos por la hegemonía, ocultados por un velo de orden y coherencia.

2015 I

Se concluye que la idea del Estado moderno está necesariamente atada a la existencia de una burocracia fuerte, organizada, técnica y legal, pero también se entiende $120 \mid$ legal-racional no es de ninguna manera prueba de desorden y caos social, sino que, por el contrario, es evidencia de maneras alternativas de organización política y ejercicio de la dominación. Se muestra que cuanto más consolidados estén los valores heredados de la modernidad en una sociedad, más fácil será la instauración de un sistema burocrático legal- racional y, por ende, menos se afectará la imagen el Estado con respecto a sus prácticas.

Además, se concluye que la gobernabilidad en muchos de los Estados contemporáneos no pasa por la distinción entre lo privado y lo público, entre lo económico y lo político, por la separación entre los bienes de los ciudadanos, los de Estado y los del administrador público; en otras palabras, no pasa por las fronteras que la modernidad marcó. La dominación y el poder en estos escenarios requieren la alianza del Estado con instituciones de carácter público al estilo moderno y de instituciones de carácter privado-societal, tales como etnias y mafias, incluso de carácter privado formal, como empresas, agremiaciones y demás. Un Estado puede echar mano tanto de la ley formal como de la moral pública o social para establecerse y mantenerse, sin perjuicio de su capacidad para presentarse ante la sociedad internacional como un Estado en sentido ortodoxo.

El proyecto de Estado moderno y soberano tuvo su tiempo, y se ha pretendido que lo que fue el Estado en determinado momento de la historia es la esencia del Estado. Pero la realidad es dinámica y cambiante, las condiciones sociales han cambiado. No se puede seguir pretendiendo establecer un orden político con teorías cuyos planteamientos se remontan al siglo XV. En este momento de la historia lo que la modernidad entendió como lo privado rebasa lo público y las formas de organización privada, tales como empresas, grupos ilegales y demás, poseen capacidades organizativas y de gestión de recursos que pueden prescindir del Estado en su papel de gran leviatán. La sociedad ya no necesita el Estado como el árbitro y la última voz en un orden político. El Estado como forma de gestión de recursos está lejos de desaparecer, de hecho cada día está más consolidado; pero entra en otro juego, un juego donde es un actor más entre múltiples actores con capacidad de negociación, de veto y control. El leviatán ha sido lanzado de su pedestal y su monolítica coherencia puesta en duda.

\section{REFERENCIAS BIBLIOGRÁFICAS}


1. Alonso Espinal, M. A. (2014). La definición del campo estatal y su relación con la guerra civil: un horizonte teórico. Estudios Políticos, 45, 135-157.

2. Bedoya, J. (2010). Se engendra un empresarismo mafiógeno. Controversia, 195, 45-73.

3. Benjamin, W. (1973). Tesis sobre filosofía de la bistoria. Madrid: Taurus.

4. Bilgin, P. y Morton, A. D. (2002). Historicising Representations of 'Failed States': Beyond the Cold-War Annexation of the Social Sciences? Third World Quarterly, 23(1), 55-80.

5. Bosch, A. (1998). La vía africana: viejas identidades, nuevos estados. Barcelona: Bellaterra.

6. Burke, P. (1993). El Renacimiento italiano: cultura y sociedad en Italia. Madrid: Alianza.

7. Chabal, P. y Daloz, J. P. (2001). África camina: el desorden como instrumento politico. Barcelona: Bellaterra.

8. Comaroff, J.y Comaroff, J. L. (2013). Teoría desde el sur o cómo los países centrales evolucionan hacia Africa. Buenos Aires: Siglo XXI.

9. Comaroff, J.y Comaroff, J. L. (2009). Violencia y ley en la poscolonia: una reflexión sobre las complicidades Norte-Sur. Buenos Aires: Katz.

10. Cruz Revueltas, J. C. (1990). ¿Qué es la política? (Antología de los mejores textos modernos). México: Publicaciones cruz O. S. A.

11. Duncan, G. (2006). Los señores de la guerra: de paramilitares, mafiosos y autodefensas en Colombia. Bogotá: Planeta.

12. Garay Salamanca, L. J. (dir.) (2008). La captura y reconfiguración cooptada del Estado en Colombia. Bogotá: Corporacion Transparencia por Colombia.

13. Habermas, J. (2008). El discurso filosófico de la modernidad. Buenos Aires: Katz.

14. Helman, G. B. y Ratner, S. R. (1993). Saving Failed States. Foreign Policy, 89, 3-20.

15. Hibou, B. (2013). De la privatización de las economias a la privatización de los Estados: análisis de la forma continua del Estado. Fondo de Cultura Económica.

16. Hobbes, Th. (1985). El leviatán, el gobierno de una república eclesiástica y civil. Bogotá: Skala.
17. López Villicaña, R. y Almazán, M. A. (2009). Somalia: Estado fallido y piratería marítima. Estudios de Asia y África, 44(3), 583-607.

18. Maritain, J. (1983). El hombre y el Estado (trad.J. M. Palacios). Madrid: Encuentro.

19. Martínez, L. (1998). Guerra civil y normalización política en Argelia. Politica Exterior, 83-96.

20. Martínez, W. (2014). A la sombra del Leviatán. Medellín: Universidad de Antioquia.

21. Mbembe, A. (2008). Al borde del mundo: fronteras, territorialidad y soberanía en África. En S. Mezzadra (comp.), Estudios poscoloniales: ensayos fundamentales (pp. 167-195). Madrid: Traficante de Sueños.

22. Mbembe, A. (2011). Necropolitica. Madrid: Melusina.

23. Méndez, E. G. (1985). Italia desde la unificación hasta 1914. Madrid: Akal.

24. Mezzadra, S. (2012). ¿Cuántas historias del trabajo? Hacia una teoría del capitalismo poscolonial. Recuperado de http://marceloexposito. net/pdf/trad_mezzadra_trabajo.pdf

25. Migdal, J. (2011). Estados débiles, Estados fuertes. México: Fondo de Cultura Económica.

26. Misse, M. (2009). El delito como parte del mercado ilegal. En R. Stanley (ed.), Estado, violencia y ciudadania en América Latina. Madrid: Antimema.

27. Misse, M. (2011). La acumulación social de la violencia en Río de Janeiro y en Brasil: algunas reflexiones. Co-herencia, 7(13), 19-40.

28. Misse, M. (2013). Economía criminal y poder político. En J. Giraldo (ed.), Economía criminal y poder político (pp. 20-50). Medellín: Universidad EAFIT.

29. Naciones Unidas, Oficina contra la Droga y el Delito (2004). Convención de las Nacione Unidas contra la Corrupción. Recuperado de http://www.unodc.org/documents/treaties/ UNCAC/Publications/Convention/0456163_S.pdf

30. Ortiz Jiménez, W. (2009). Los paraestados en Colombia: fundamentación teórica y salidas politicas. Medellín: Universidad Autónoma Latinoamericana.

I Panorama

pp. 104-122

I Volumen 9

I Número 17

31. Pace, G. (2010). ¿Es hoy posible un estado mafioso en Europa?: un análisis del caso italiano. Controversia, 195, 11-44. 
Juan Pablo

Henao Guzmán I

32. Pareja M., D. J. (2015). Presupuesto participativo de Medellín estaría en manos de delincuentes. El Tiempo. Recuperado de http:// www.eltiempo.com/colombia/medellin/ presupuesto-participativo-de-medellin-estaria-en-manos-de-delincuentes/15173395

33. Prats, J. (2005). De la burocracia al management, del management a la gobernanza: las transformaciones de las administraciones públicas de nuestro tiempo. Madrid: Instituto Nacional de Administración Pública.

34. Reno, W. (2013). Problemas de la mafia, crisis de los señores de la guerra. En J. Giraldo (ed.), Economía criminal y poder político (pp. 69-113). Medellín: Universidad EAFIT.

35. Schutz, A. (1993). La conducción significativa del mundo social. Barcelona: Paidós.

36. Strayer, J. (1981). Sobre los orígenes medievales del Estado moderno. Barcelona: Ariel.

37. Tilly, Ch. (2006). Guerra y construcción del Estado como crimen organizado. Revista Académica de Relaciones Internacionales, 5, 1-26.

38. Uribe, M. (2001). Nación, ciudadano y soberano. Medellín: Corporación Región.

39. Weber, M. (1964). Economía y sociedad: esbozo de la sociología comprensiva. México: Fondo de Cultura Económica.

40. Weber, M. (1980). El politico y el cientifico. México: Premia.

41. Zabludovsky, G. (1986). Max Weber y la dominación patrimonial en América Latina. Revista Mexicana de Ciencias Politicas y Sociales, 23, 75-96. 